\title{
FRAGMEN TARI SUGRIWA SUBALI KARYA DIDIK BAMBANG WAHYUDI (TINJAUAN ESTETIK)
}

\author{
Annisa Ayu Cahyani \\ Institut Seni Indonesia (ISI) Surakarta \\ Jalan Ki Hajar Dewantara No. 19 Kentingan, Jebres, Surakarta 57126 \\ Maryono \\ Institut Seni Indonesia (ISI) Surakarta
}

\begin{abstract}
Research entitled Sugriwa Subali Dance Fragment by Didik Bambang Wahyudi (Aesthetic Review) is aim to uncover the meaning beauty of Sugriwa Subali Dance Fragment by describes and explains abaout: (1) the shape or sensation of Sugriwa Subali Dance Fargment which cover: theme, motion, expression, floor patterns, make-up, clothing, property and dance music/musical instruments, (2) to explain the concepts or ideas in the Sugriwa Subali Dance Fragment, (3) to explain the aestetic symbols in the Sugriwa Subali Dance Fragment, and (4) audience responses include: the responses of experts, dancers, and spectator. The four problems are examined with aestetic theory De Witt H Parker. In its application to analyze shapes as sensation expressed in the work using performance art theory according to Maryono. Analysis of consepts or idea in the work uses a pragmatic approach with Kreidler's speech act theory. The research is qualitatively by collecting data or information through the stage of presenting dance work (re-production), literature study, interviews with selected speakers, and observation of the Sugriwa Subali Dance Fragment. The result was: the dance work is based on sensations, concepts or ideas, symbols, and the responses of experts, dancers, and spectator aestetically. Sugriwa Subali Dance Fragement is the masterpiece of the battle between Sugriwa and Subali fight over to Dewi Tara and the funcions as an aesthetic entertainment and as a symbol of strunggle in obtaining a happiness.
\end{abstract}

Keywords: Fragment of Sugriwa Subali Dance, aesthetic.

\section{PENDAHULUAN}

Fragmen Tari Sugriwa Subali karya Didik Bambang Wahyudi disusun pada tahun 1988. Fragmen Tari Sugriwa Subali merupakan karya tari berbentuk fragmen yang merujuk pada cerita epos Ramayana episode Sugriwa Subali yang menceritakan tentang perselisihan tokoh Sugriwa dan Subali (Didik Bambang Wahyudi, wawancara 17 Oktober 2019). Fragmen menurut pengertian Maryono menyatakan bahwa:

Fragmen merupakan jenis garapan dramatari bersekala kecil yang disajikan lebih dari dua penari hingga mencapai enam penari. Kehadiran fragmen tari merupakan alternatif garapan dramatari yang dalam penyajiannya tidak menuntut banyak penari (2015:8). 
Fragmen Tari Sugriwa Subali mengungkapkan peperangan antara Sugriwa dan Subali dalam memperebutkan Dewi Tara. Dewi Tara merupakan hadiah dari Dewa sebagai imbalan untuk Sugriwa atau Subali ketika berhasil mengalahkan Mahesasura Raja sakti mandraguna dari Goa Kiskendha dan kedua patihnya Jatasura dan Lembusura. Fragmen Tari Sugriwa Subali menampilkan tiga tokoh yaitu Sugriwa, Subali, dan Dewi Tara. Tokoh Sugriwa dan Subali termasuk dalam tari gagah gaya Surakarta dengan karakter khusus wanara, sedangkan Dewi Tara dalam lakon pewayangan merupakan gambaran seorang bidadari yang memiliki karakter putri luruh. Pada Fragmen Tari Sugriwa Subali masing-masing tokoh Sugriwa dan Subali memiliki karakter yang berbedabeda. Perbedaan karakter diantara Sugriwa dan Subali yaitu Sugriwa memiliki karakter gagah lincah trengginas dan pantang menyerah, sedangkan Subali memiliki karakter gagah antep atau tenang, berwibawa, dan trengginas. Untuk Dewi Tara dalam karya ini ditafsirkan dalam tokoh putri luruh yang bernuansa lanyap, dengan tujuan untuk dapat membangun suasana yang diinginkan oleh koreografer.

Berdasarkan pernyataan tersebut secara esensi Fragmen Tari Sugriwa Subali pada dasarnya ingin mengungkapkan hak dan kebenaran yang dimiliki oleh Sugriwa dan Subali. Hak dan kebenaran milik Sugriwa dan Subali dirujuk dari perselisihan kesalahpahaman atas anugrah Dewa yaitu Dewi Tara. Nilai-nilai hak dan kebenaran yang terdapat dalam Fragmen Tari Sugriwa Subali rupanya layak untuk diteliti dari segi estetis. Kehadiran Fragmen Tari Sugriwa Subali juga berperan penting dalam lingkup pendidikan yang digunakan sebagai salah satu materi Ujian Tugas Akhir minat kepenarian di Institut Seni Indonesia Surakarta. Selain itu juga untuk memperkaya khasanah kehidupan tari sebagai kesenian tradisi khususnya tari tradisi gaya Surakarta.

Untuk mengungkap makna Fragmen Tari Sugriwa Subali, digunakan teori estetika menurut De Witt H Parker. Secara jelas Parker menyatakan bahwa setiap pengalaman seni atau pengalaman estetik itu mengandung sensasi atau bentuk, konsep atau gagasan, simbolisasi, dan emosional atau tanggapan penonton (1980:76-78).

\section{BENTUK SENSASI}

Bentuk adalah media ungkapan yang secara visual dapat ditangkap oleh indra manusia yang dapat dilukiskan sebagai sebuah pernyataan suatu maksud, perasaan, ataupun pikiran dengan suatu medium indra atau yang dapat dialami atau dihayati lagi oleh yang mengungkapkan (Maryono, 2012:97).

Bentuk dalam tari merupakan wujud keseluruhan dari sistem, kompleksitas berbagai unsur-unsurnya yang membentuk suatu jalinan atau kesatuan, saling terikat secara utuh, sehingga mampu memberikan daya apresiasi. Menurut Maryono bentuk tari secara garis besar terdiri dari komponenkomponen dasar yang dapat dibedakan menjadi dua, yaitu: komponen verbal, dan komponen nonverbal (2015:24). Komponen nonverbal dalam seni pertunjukan berfungsi sebagai penyampai isi atau pesan makna dari seorang koreografer atau penyusun tari terhadap penonton (Maryono, 2015:51). Secara garis besar dapat dinyatakan bahwa komponen nonverbal itu merupakan 
media penyampai yang berfungsi sebagai sensasi ungkap dalam tari. Komponen yang bersifat nonverbal dalam karya Fragmen Tari Sugriwa Subali terdiri dari tema, gerak tubuh, polatan/ekspresi wajah, rias, busana, pola lantai, properti, dan karawitan tari. Berikut analisis komponen nonverbal Fragmen Tari Sugriwa Subali.

\section{Tema}

Tema dalam tari merupakan rujukan cerita yang dapat menghantarkan seseorang pada pemahaman esensi. Tema dapat ditarik dari sebuah peristiwa atau cerita, yang selanjutnya dijabarkan menjadi alur cerita sebagai kerangka sebuah garapan (Maryono, 2010: 53). Tema dalam karya Fragmen Tari Sugriwa Subali merujuk pada kisah cerita Ramayana dalam Episode Sugriwa Subali. Menurut koreografer dalam karya ini lebih fokus pada perselisihan tokoh Sugriwa dan Subali. Kehadiran Dewi Tara dalam karya ini ditujukan sebagai ungkapan permasalahan atau konflik yang terjadi diantara Sugriwa dan Subali. Dengan tujuan supaya cerita yang diangkat dapat tersampaikan dengan baik kepada penonton. Menurut Didik Bambang Wahyudi, Fragmen Tari Sugriwa Subali mengungkapkan tema percintaan dan peperangan. Percintaan yang dimaksud adalah kisah cinta dua wanara bersaudara dengan seorang bidadari berparas cantik bernama Dewi Tara. Sedangkan peperangan yang dimaksudkan adalah peperangan antara Sugriwa dan Subali dalam memperebutkan Dewi Tara karena terjadi suatu kesalahpahaman (Didik Bambang Wahyudi, wawancara 17 Oktober 2019).

\section{Polatan atau ekspresi wajah}

Ekspresi atau polatan merupakan perubahan kondisi visual raut muka atau wajah seseorang. Ekpresi wajah merupakan sarana untuk mendapatkan pemahaman dan gambaran kondisi psikologis seseorang (Maryono, 2015: 56). Ekspresi wajah dalam tokoh Sugriwa dan Subali sebagian besar telah dibentuk dengan rias karakter wanara. Tokoh Dewi Tara masuk dalam karakter putri luruh yang bernuansa lanyap. Ekpresi wajah atau polatan yang ditampilkan pada setiap adegan tampak berbeda-beda, tergantung dari suasana yang ingin disampaikan. Berikut merupakan penjelasan ekspresi atau polatan dalam karya Fragmen Tari Sugriwa Subali.

Babak pertama adegan pasihan, polatan Dewi Tara kea rah sudutbawah, didukung dengan vokabuler gerak putri luruh sebagai penggambaran keanggunan dan kecantikan seorang bidadari dan mengungkapkan suasana hati yang sedang berbunga-bunga. Sugriwa muncul dengan polatan ke Dewi Tara. Secara garis besar dalam babak ini mengungkapkan sepasang kekasih yang sedang bercengkrama dan memadu kasih dengan suasana yang ceria, penuh kasih dan didukung dengan vokabuler gerak yang memunculkan kesan kenes pada tokoh Dewi Tara dan kesan sigrak pada tokoh Sugriwa.

Babak kedua adegan perebutan Dewi Tara diawali munculnya tokoh Subali sebagai awal konflik. Polatan Subali tajam dengan arah pandangan lurus jauh ke depan disertai dengan ekspresi wajah marah, didukung pula dengan adanya cangkeman. Sugriwa menghadirkan ekspresi terkejut dan kebingungan, dengan polatan tajam. Dewi Tara memunculkan ekspresi kebingungan, 
didukung dengan gerak- gerak yang tegas. Secara garis besar dalam adegan ini menggunakan polatan mata yang tajam dengan ekspresi kemarahan sebagai ungkapan konflik yang terjadi antara tokoh Sugriwa dan Subali.

Babak ketiga adegan beksan, polatan yang digunakan tokoh Sugriwa dan Subali adalah polatan tajam dengan arah pandangan mata lurus ke depan tegas, serta didukung dengan vokabuler gerak-gerak dengan tekanan yang keras, lincah dan terlihat gagah sebagai penggambaran seorang kesatria. Secara garis besar suasana yang dihadirkan dalam adegan beksan ini yaitu suasana agung yang diselingi dengan suasana tegang karena adanya suatu perlawanan antara Sugriwa dan Subali. Adegan perang tangkepan menggunakan polatan yang tajam dengan arah pandangan selalu mengarah ke arah lawan, sebagai ungkapan kewaspadaan ketika mendapat serangan lawan. Didukung dengan gerakgerak yang gesit, cekatan, dan gerak-gerak yang tegas. Suasana yang didapat yaitu suasana tegang dalam peperangan.

Adegan perang gaman menggunakan properti berupa gada. Polatan yang digunakan hampir sama dengan adegan perang tangkepan, hanya saja ditambah dengan gestur tubuh seperti menuding dengan menggunakan properti gada. Dalam adegan ini gestur tersebut hadir karena adanya ungkapan yang terdapat di dalam syair palaran. Akhir babak tiga diungkapkan dengan polatan Subali yang tajam dengan penuh angkara murka terhadap Sugriwa. Polatan Sugriwa sudah mulai berkurang ketajamannya namun arah pandangan tetap menatap Subali dengan ekspresi memelas. Dalam adegan ini Sugriwa sudah tidak berdaya lagi karena terus diserang dan didesak oleh Subali.

\section{Gerak}

Gerak dalam tari tradisi memiliki arti dan kedudukan sentral, lewat gerak kita dapat mengetahui dan memahami tentang makna simbolis yang terkandung dalam pertunjukan tari (Maryono, 2015:90). Gerak dalam tari secara garis besar dapat dibagi menjadi dua kelompok yaitu gerak presentatif atau murni dan gerak representatif atau penghadir. Gerak presentatif atau murni adalah jenis gerak yang difungsikan semata-mata untuk kebutuhan ekspresi. Sedangkan gerak representatif atau gerak penghadir adalah gerak yang dihasilkan dari imitasi terhadap sesuatu (Maryono, 2015:54-55).

Berdasarkan pembagian kedua jenis gerak tersebut, selanjutnya peneliti gunakan untuk mengkaji jenis- jenis gerak yang terdapat pada garapan karya Fragmen Tari Sugriwa Subali.

Tabel 1. Jenis-jenis gerak Representatif pada babak pertama.

\begin{tabular}{|c|c|c|c|}
\hline \multirow{2}{*}{ No } & \multirow{2}{*}{ Tokoh } & Jenis Gerak & \multirow{2}{*}{ Keterangan } \\
\hline & & Representatif & \\
\hline \multicolumn{4}{|c|}{ Adegan pasihan antara Dewi Tara dan Sugriwa } \\
\hline \multirow{15}{*}{1} & \multirow{15}{*}{ Dewi Tara } & Srisig menthang & Stilisasi berlari \\
\hline & & Srisig methang & Stilisasi berlari \\
\hline & & Gedheg & $\begin{array}{l}\text { Stilisasi gerak kepala ke kanan dan } \\
\text { ke kiri }\end{array}$ \\
\hline & & $\begin{array}{l}\text { Srisig sampir } \\
\text { sampur }\end{array}$ & Stilisasi orang sedang berlari \\
\hline & & Enjer & $\begin{array}{l}\text { Stilisasi orang yang sedang berjalan } \\
\text { ke samping }\end{array}$ \\
\hline & & Srisig menthang & Stilisasi orang sedang berlari \\
\hline & & Endhan & Stilisasi gerak menghindar \\
\hline & & Srisig mundur & Stilisasi jalan mundur \\
\hline & & Srisig mundur & Stilisasi jalan mundur \\
\hline & & Srisig mundur & Stilisasi jalan mundur \\
\hline & & Ulap-ulap tawing & $\begin{array}{l}\text { Stilisasi orang sedang melihat ke } \\
\text { samping }\end{array}$ \\
\hline & & $\begin{array}{l}\text { Lumaksono ridhong } \\
\text { sampur }\end{array}$ & Stilisasi berjalan \\
\hline & & Srisig kipat sampur & Stilisasi berlari \\
\hline & & $\begin{array}{l}\text { Lumaksono ridhong } \\
\text { sampur }\end{array}$ & Stilisasi berjalan \\
\hline & & Ngulung sampur & Memberikan sampur dan Mengajak \\
\hline
\end{tabular}




\begin{tabular}{|c|c|c|c|}
\hline \multirow{18}{*}{2} & \multirow{18}{*}{ Sugriwa } & Srisig & Stilisasi berlari \\
\hline & & Ulap-ulap kambeng & Stilisasi melihat \\
\hline & & Nginguk & Stilisasi kera sedang melihat \\
\hline & & Srisig kambeng & Stilisasi berlari \\
\hline & & Njawil & Stilisasi gerak menyentuh sesuatu \\
\hline & & Trap jamang & $\begin{array}{l}\text { Stilisasi gerak tangan saat } \\
\text { melihat sesuatu }\end{array}$ \\
\hline & & Laku telu & Stilisasi berjalan di tempat \\
\hline & & $\begin{array}{l}\text { Nginguk/linglingan } \\
\text { tranjalan }\end{array}$ & $\begin{array}{l}\text { Stilisasi gerak sedang } \\
\text { melihat sesuatu }\end{array}$ \\
\hline & & Enjer kambengan & Stilisasi berjalan miring \\
\hline & & Srisig kambeng & Stilisasi berlari \\
\hline & & Candaan kanan kiri & $\begin{array}{l}\text { Stilisasi gerak menirukan kera } \\
\text { saat akan meraih sesuatu }\end{array}$ \\
\hline & & Nginguk & Stilisasi kera sedang melihat \\
\hline & & Jalan jengkengan & Stilisasi gerak berjalan \\
\hline & & Nginguk & Stilisasi kera sedang melihat \\
\hline & & Ngglebag & Stilisasi gerak membalikkan badan \\
\hline & & Nampani sampur & Stilisasi gerak menerima sesuatu \\
\hline & & Srisig kambengan & Stilisasi gerak berlari \\
\hline & & $\begin{array}{l}\text { Lukasono } \\
\text { kambengan }\end{array}$ & Stilisasi gerak berjalan \\
\hline
\end{tabular}

\section{Tabel 2. Jenis-jenis gerak Presentatif pada babak pertama.}

\begin{tabular}{|c|c|c|c|}
\hline \multirow{2}{*}{ No } & \multirow{2}{*}{ Tokoh } & Jenis Gerak & \multirow{2}{*}{ Keterangan } \\
\hline & & Presentatif & \\
\hline \multicolumn{4}{|c|}{ Adegan pasihan antara Dewi Tara dan Sugriwa } \\
\hline \multirow{25}{*}{1} & \multirow{25}{*}{ Dewi Tara } & Kengser menthang & Kesan menjauh/ berpindah tempat \\
\hline & & Impur kanan & $\begin{array}{l}\text { Kesan berliku-liku, merubah arah } \\
\text { hadap tubuh }\end{array}$ \\
\hline & & Lembehan separo & Kesan tenang dan lembut \\
\hline & & Kengser menthang & Kesan menjauh \\
\hline & & Ngglebag menthang & $\begin{array}{l}\text { Kesan berliku-liku, merubah arah } \\
\text { hadap tubuh }\end{array}$ \\
\hline & & Jengkeng panggel & $\begin{array}{l}\text { Kesan sedang menunggu dan } \\
\text { menghormati }\end{array}$ \\
\hline & & $\begin{array}{l}\text { Ngglebag sampir } \\
\text { sampur }\end{array}$ & Kesan merubah arah hadap \\
\hline & & $\begin{array}{l}\begin{array}{l}\text { Ngglebag } \\
\text { sampur }\end{array} \text { seblak } \\
\end{array}$ & $\begin{array}{l}\text { Kesan berliku-liku, merubah arah } \\
\text { hadap tubuh }\end{array}$ \\
\hline & & Sekaran timbo-timbo & Kesan cantik dan lembut \\
\hline & & Panggel mendhut & Kesan cantik dan lembut \\
\hline & & Sindhet & Gerak penghubung \\
\hline & & Kengser menthang & Kesan berpindah tempat \\
\hline & & Ngglebag & Kesan mengubah arah hadap \\
\hline & & Sekaran golek iwak & Kesan tenang \\
\hline & & Sindhet & Gerak penghubung \\
\hline & & Sekaran sukarsih & Kesan kenes \\
\hline & & Kengser & Kesan menjauh \\
\hline & & Kebyok ngleyang & Kesan manis \\
\hline & & $\begin{array}{l}\text { kebyak njujut kedua } \\
\text { kaki }\end{array}$ & Kesan manis \\
\hline & & Hoyogan ulap-ulap & Kesan menjauh \\
\hline & & ngglebag ngleyang & Kesan mengubah arah hadap \\
\hline & & ngglebag & Kesan mengubah arah hadap \\
\hline & & Hoyogan & Kesan tenang \\
\hline & & Sabetan & Gerak penghubung \\
\hline & & $\begin{array}{l}\text { Nglebag seblak } \\
\text { kedua sampur }\end{array}$ & Kesan menjauh \\
\hline \multirow[t]{7}{*}{2} & \multirow[t]{7}{*}{ Sugriwa } & $\begin{array}{ll}\begin{array}{l}\text { kambengan } \\
\text { dan kiri }\end{array} & \\
\end{array}$ & Kesan gagah \\
\hline & & $\begin{array}{l}\text { Sekaran kambeng kanan } \\
\text { kiri }\end{array}$ & Kesan gagah \\
\hline & & $\begin{array}{l}\text { Hoyogan kambengan } \\
\text { jengkeng }\end{array}$ & Kesan gagah \\
\hline & & Lompat katak & $\begin{array}{l}\text { Kesan tertawa, kesan bahagia, } \\
\text { kegirangan }\end{array}$ \\
\hline & & Tranjalan & Kesan lincah dan trengginas \\
\hline & & Tranjal & Kesan lincah \\
\hline & & Onclangan ulap-ulap & \\
\hline
\end{tabular}

Tabel3. Jenis-jenis gerak Representatif pada babak kedua.

\begin{tabular}{|c|c|c|c|}
\hline \multirow{2}{*}{ No } & \multirow{2}{*}{ Tokoh } & Jenis Gerak & \multirow{2}{*}{ Keterangan } \\
\hline & & Representatif & \\
\hline \multicolumn{4}{|c|}{ Adegan perebutan Dewi Tara oleh Sugriwa dan Subali } \\
\hline 1 & Sugriwa & Ngglebag & Stilisasi gerak membalikkan badan \\
\hline \multirow{4}{*}{2} & \multirow{4}{*}{ Subali } & Lumaksono & Stilisasi sedang berjalan \\
\hline & & \begin{tabular}{|l|} 
Ngglebag \\
\end{tabular} & Stilisasi gerak membalikkan badan \\
\hline & & \begin{tabular}{|l} 
Lari \\
\end{tabular} & Stilisasi gerak berlari cepat \\
\hline & & Mbalik awak & Stilisasi gerak memalingkan muka \\
\hline \multirow{4}{*}{3} & \multirow{4}{*}{ Dewi Tara } & Kapang-kapang & Stilisasi orang berjalan \\
\hline & & $\begin{array}{l}\text { Ngglebag seblak } \\
\text { kedua sampur }\end{array}$ & $\begin{array}{l}\text { Stilisasi gerak membalikkan badan } \\
\text { ketika menghindar }\end{array}$ \\
\hline & & $\begin{array}{l}\text { Ulap-ulap tawing } \\
\text { kanan }\end{array}$ & $\begin{array}{l}\text { Stilisasi orang sedang melihat ke } \\
\text { samping }\end{array}$ \\
\hline & & $\begin{array}{l}\text { Srisig mentang } \\
\text { sampur kiri }\end{array}$ & Stilisasi orang berlari \\
\hline \multirow{11}{*}{4} & \multirow{11}{*}{ Sugriwa } & Onclang kambengan & $\begin{array}{l}\text { Stilisasi gerak melompat berpindah } \\
\text { tempat }\end{array}$ \\
\hline & & \begin{tabular}{|l|}
$\begin{array}{l}\text { Lumaksono kambeng } \\
\text { jengkengan }\end{array}$ \\
\end{tabular} & Stilisasi gerak berjalan \\
\hline & & Ngglebag muter & Stilisasi gerak membalikkan badan \\
\hline & & Candaan kanan & $\begin{array}{l}\text { Stilisasi gerak kera menyentuh } \\
\text { sesuatu }\end{array}$ \\
\hline & & \begin{tabular}{|l|} 
Ngglebag \\
\end{tabular} & Stilisasi gerak membalikkan badan \\
\hline & & Onclang & $\begin{array}{l}\text { Stilisasi gerak melompat untuk } \\
\text { berpindah tempat }\end{array}$ \\
\hline & & \begin{tabular}{|l} 
Jalan jengkengan \\
\end{tabular} & Stilisasi gerak berjalan \\
\hline & & Ngglebag & Stilisasi gerak membalikkan badan \\
\hline & & Onclangan & $\begin{array}{l}\text { Stilisasi gerak melompat untuk } \\
\text { berpindah tempat }\end{array}$ \\
\hline & & Perang tangkepan & $\begin{array}{l}\text { Stilisasi orang berperang dengan } \\
\text { tangan kosong }\end{array}$ \\
\hline & & \begin{tabular}{|l} 
Lompat katak \\
\end{tabular} & Stilisasi gerak melompat \\
\hline \multirow{11}{*}{5} & \multirow{11}{*}{ Subali } & Onclang kambengan & $\begin{array}{l}\text { Stilisasi gerak melompat berpindah } \\
\text { tempat }\end{array}$ \\
\hline & & $\begin{array}{l}\begin{array}{l}\text { Lumaksono kambeng } \\
\text { jengkengan }\end{array} \\
\end{array}$ & Stilisasi gerak berjalan \\
\hline & & Ngglebag muter & Stilisasi gerak membalikkan badan \\
\hline & & Njangkah cepat & Stilisasi gerak berjalan cepat \\
\hline & & Ngglebag & Stilisasi gerak membalikkan badan \\
\hline & & Ngginguk & Stilisasi gerak melihat sesuatu \\
\hline & & $\begin{array}{l}\text { Lumaksono } \\
\text { kambengan }\end{array}$ & Stilisasi gerak berjalan \\
\hline & & Ngglebag & Stilisasi gerak membalikkan badan \\
\hline & & Onclangan & $\begin{array}{l}\text { Stilisasi gerak melompat untuk } \\
\text { berpindah tempat }\end{array}$ \\
\hline & & \begin{tabular}{|l|} 
Perang tangkepan \\
\end{tabular} & Perang dengan tangan kosong \\
\hline & & Lompat katak & Stilisasi gerak melompat \\
\hline \multirow[t]{4}{*}{6} & \multirow[t]{4}{*}{ Dewi Tara } & $\begin{array}{l}\text { Ngglebag seblak } \\
\text { sampur }\end{array}$ & Stilisasi gerak membalikkan badan \\
\hline & & Srisig mundur & Stilisasi gerak berjalan mundur \\
\hline & & Srisig ngiting & Stillisasi gerak berlari \\
\hline & & Kapang-kapang & Stilisasi orang berjalan \\
\hline \multirow[t]{3}{*}{7} & \multirow[t]{3}{*}{ Sugriwa } & Ulap-ulap kambeng & Stilisasi gerak melihat ke samping \\
\hline & & \begin{tabular}{|l} 
Ngglebag muter \\
\end{tabular} & Stilisasi gerak membalikkan badan \\
\hline & & Jalan lompat & Stilisasi gerak berjalan \\
\hline \multirow[t]{4}{*}{8} & \multirow[t]{4}{*}{ Subali } & Ulap-ulap kambeng & Stilisasi gerak melihat ke samping \\
\hline & & Njangkah mundur & Stilisasi gerak jalan mundur \\
\hline & & Ngglebag muter & Stilisasi gerak membalikkan badan \\
\hline & & Prenjak tinaji & $\begin{array}{l}\text { Stilisasi gerak burung tinaji saat } \\
\text { berjalan }\end{array}$ \\
\hline \multirow[t]{2}{*}{9} & \multirow[t]{2}{*}{ Dewi tara } & Ulap-ulap tawing & Stilisasi gerak melihat ke samping \\
\hline & & Srisig menthang kanan & Stilisasi gerak berlari \\
\hline \multirow[t]{2}{*}{10} & Sugriwa & Jalan miring & Stilisasi orang berjalan \\
\hline & & Duduk sempok & Stilisasi gerak duduk tanpa alas \\
\hline 11 & Subali & Tangkis & Stilisasi gerak memukul \\
\hline & & \begin{tabular}{|l|} 
Jalan miring \\
\end{tabular} & Stilisasi orang berjalan \\
\hline & & Duduk sempok & Stilisasi gerak duduk tanpa alas \\
\hline
\end{tabular}


Tabel 4. Jenis-jenis gerak Presentatif pada babak kedua.

\begin{tabular}{|c|c|c|c|}
\hline \multirow{2}{*}{ No } & \multirow{2}{*}{ Tokoh } & Jenis Gerak & \multirow{2}{*}{ Keterangan } \\
\hline & & Presentatif & \\
\hline \multicolumn{4}{|c|}{ Adegan perebutan Dewi Tara oleh Sugriwa dan Subali } \\
\hline \multirow[t]{5}{*}{1} & \multirow[t]{5}{*}{ Sugriwa } & Mere & Kesan terkejut \\
\hline & & $\begin{array}{l}\text { Geleng-geleng kepala, } \\
\text { putar, onclang jalan } \\
\text { jengkengan }\end{array}$ & Kesan kebingungan dan panik \\
\hline & & Tanjak tancep & Kesan gagah \\
\hline & & Jengkengan kambeng & Kesan kebingungan \\
\hline & & Mere & Kesan marah \\
\hline \multirow[t]{3}{*}{2} & \multirow[t]{3}{*}{ Subali } & Mere & Kesan marah \\
\hline & & Tanjak kambeng & Kesan gagah \\
\hline & & Mere & Kesan marah \\
\hline 3 & Dewi Tara & Jengkeng panggel & Kesan sedang menunggu \\
\hline \multirow[t]{7}{*}{4} & \multirow{7}{*}{ Sugriwa } & Mere & Kesan marah \\
\hline & & Tanjak tancep & Kesan gagah \\
\hline & & Roll depan & Kesan gerak reaksi (akibat) \\
\hline & & Mere & Kesan marah \\
\hline & & Lompat tendang & Kesan marah, menyerang \\
\hline & & Roll depan & Kesan gerak reaksi (akibat) \\
\hline & & Mere & Kesan marah \\
\hline \multirow[t]{6}{*}{5} & \multirow[t]{6}{*}{ Subali } & Mere & Kesan marah \\
\hline & & Tanjak tancep & Kesan gagah \\
\hline & & Sikut & Kesan menangkis \\
\hline & & Tendang & Kesan menyerang lawan \\
\hline & & Lari lompat & Kesan tergesa-gesa \\
\hline & & Mere & Kesan marah \\
\hline \multirow[t]{2}{*}{6} & \multirow[t]{2}{*}{ Dewi Tara } & $\begin{array}{l}\text { Srisig maju mundur } \\
\text { seblak kedua sampur }\end{array}$ & Kesan kebingungan \\
\hline & & Seblak kedua sampur & $\begin{array}{l}\text { Kesan memisahkan sesuatu saat } \\
\text { bertengkar }\end{array}$ \\
\hline \multirow[t]{2}{*}{7} & \multirow[t]{2}{*}{ Sugriwa } & Srimpet tanjak tancep & Kesan gagah saat berpindah \\
\hline & & Candaan kiri & Kesan menghentikan \\
\hline 8 & Subali & Tanjak kambeng & Kesan menunggu \\
\hline 9 & Dewi Tara & Kengser & Kesan manis saat berpindah tempat \\
\hline \multirow[t]{4}{*}{10} & \multirow[t]{4}{*}{ Sugriwa } & Geleng & Kesan tertangkis sesuatu \\
\hline & & Gapruk & Kesan memukul \\
\hline & & Onclangan yogjan & Kesan peperangan hebat \\
\hline & & Gapruk & Kesan memukul \\
\hline \multirow[t]{3}{*}{11} & \multirow[t]{3}{*}{ Subali } & Gapruk & Kesan memukul \\
\hline & & Onclangan yogjan & Kesan peperangan hebat \\
\hline & & Gapruk & Kesan memukul \\
\hline
\end{tabular}

Tabel 5. Jenis-jenis gerak Representatif pada babak ketiga.

\begin{tabular}{|c|c|c|c|}
\hline \multirow{2}{*}{ No } & \multirow{2}{*}{ Tokoh } & Jenis Gerak & \multirow{2}{*}{ Keterangan } \\
\hline & & Representatif & \\
\hline \multicolumn{4}{|c|}{ Adegan Beksan } \\
\hline 1 & Sugriwa & $\begin{array}{l}\text { Ulap-ulap } \\
\text { kambengan }\end{array}$ & Melihat ke samping \\
\hline \multirow{12}{*}{2} & \multirow{12}{*}{ Subali } & $\begin{array}{l}\text { Ulap-ulap } \\
\text { kambengan }\end{array}$ & Melihat ke samping \\
\hline & & Nginguk & $\begin{array}{l}\text { Stilisasi gerak kera sedang melihat } \\
\text { sesuatu }\end{array}$ \\
\hline & & Ngglebag muter & $\begin{array}{l}\text { Stilisasi gerak orang membalikkan } \\
\text { badan }\end{array}$ \\
\hline & & Onclangan & $\begin{array}{l}\text { Stilisasi gerak melompat berpindah } \\
\text { tempat }\end{array}$ \\
\hline & & $\begin{array}{l}\text { Ulap-ulap } \\
\text { kambengan }\end{array}$ & Melihat ke samping \\
\hline & & $\begin{array}{l}\text { Oclangan ulap-ulap } \\
\text { yogjan }\end{array}$ & Stilisasi gerak lompat berjalan \\
\hline & & Prenjak tinaji & $\begin{array}{l}\text { Menirukan gerak kera saat berlari } \\
\text { kecil-kecil }\end{array}$ \\
\hline & & $\begin{array}{l}\text { Oclangan ulap-ulap } \\
\text { yogjan }\end{array}$ & Stilisasi gerak lompat berjalan \\
\hline & & Tangkepan kanan & Stilisasi gerak perang \\
\hline & & Pukul atas & Stilisasi gerak memukul \\
\hline & & Lompat lenting & Stilisasi gerak melompat \\
\hline & & Ngginguk & $\begin{array}{l}\text { Stilisasi gerak kera sedang melihat } \\
\text { sesuatu }\end{array}$ \\
\hline
\end{tabular}

\begin{tabular}{|c|c|c|c|}
\hline & & Lampah tigo & $\begin{array}{l}\text { Stilisasi gerak berjalan maju- } \\
\text { mundur }\end{array}$ \\
\hline & & Mere & Kesan marah \\
\hline & & Nginguk & $\begin{array}{l}\text { Stilisasi gerak kera sedang melihat } \\
\text { sesuatu }\end{array}$ \\
\hline & & Ngglebag muter & $\begin{array}{l}\text { Stilisasi gerak orang membalikkan } \\
\text { badan }\end{array}$ \\
\hline \multirow{8}{*}{3} & \multirow{8}{*}{ Sugriwa } & Ngglebag muter & $\begin{array}{l}\text { Stilisasi gerak orang membalikkan } \\
\text { badan }\end{array}$ \\
\hline & & $\begin{array}{l}\text { Oclangan ulap-ulap } \\
\text { yogjan }\end{array}$ & Stilisasi gerak lompat berjalan \\
\hline & & Prenjak tinaji & $\begin{array}{l}\text { Menirukan gerak kera saat berlari } \\
\text { kecil-kecil }\end{array}$ \\
\hline & & $\begin{array}{l}\text { Onclangan ulap-ulap } \\
\text { yogjan }\end{array}$ & Melompat sambil berpindah tempat \\
\hline & & Jalan miring & Stilisasi gerak berjalan ke samping \\
\hline & & Lampah tigo & $\begin{array}{l}\text { Stilisasi gerak berjalan maju- } \\
\text { mundur }\end{array}$ \\
\hline & & Ulap-ulap tranjalan & Gerak sekaran \\
\hline & & Tusuk kiri & $\begin{array}{l}\text { Stilisasi gerak } \\
\text { menyerang } \\
\text { lawan/memukul }\end{array}$ \\
\hline \multicolumn{4}{|c|}{ Adegan perang tengkepan } \\
\hline \multirow[b]{2}{*}{4} & & Capengan & Stilisasi gerak membenarkan atribut \\
\hline & Sugriwa & Perang tangkepan & $\begin{array}{l}\text { Stilisasi gerak perang } \\
\text { tanpa menggunakan } \\
\text { senjata }\end{array}$ \\
\hline 5 & Subali & Perang tangkepan & $\begin{array}{l}\text { Stilisasi gerak perang tanpa } \\
\text { menggunakan senjata }\end{array}$ \\
\hline \multicolumn{4}{|c|}{ Adegan perang gaman } \\
\hline \multirow{3}{*}{6} & \multirow{3}{*}{ Sugriwa } & Mengambil gada & Stilisasi gerak mengambil sesuatu \\
\hline & & Perang gaman & $\begin{array}{l}\text { Stilisasi gerak perang menggunakan } \\
\text { senjata }\end{array}$ \\
\hline & & Menangkap gada & Stilisasi gerak menangkap sesuatu \\
\hline \multirow{6}{*}{7} & \multirow{6}{*}{ Subali } & Nginguk & Stilisasi gerak melihat \\
\hline & & Lompat sempok & Stilisasi gerak lompat \\
\hline & & Melempar gada & Stilisasi gerak melempar sesuatu \\
\hline & & Perang gaman & $\begin{array}{l}\text { Stilisasi gerak perang menggunakan } \\
\text { senjata }\end{array}$ \\
\hline & & Lumaksono & Stilisasi gerak berjalan \\
\hline & & Nginguk & Stilisasi gerak melihat \\
\hline
\end{tabular}

\section{Tabel 6. Jenis-jenis gerak Presentatif pada babak ketiga.}

\begin{tabular}{|c|c|c|c|}
\hline \multirow{2}{*}{ No } & \multirow{2}{*}{ Tokoh } & Jenis Gerak & \multirow{2}{*}{ Keterangan } \\
\hline & & Presentatif & \\
\hline \multicolumn{4}{|c|}{ Adegan perebutan Dewi Tara oleh Sugriwa dan Subali } \\
\hline 1 & Sugriwa & Tanjak tancep & Kesan gagah \\
\hline \multirow{19}{*}{2} & \multirow{14}{*}{ Subali } & Tanjak tancep & Kesan gagah \\
\hline & & Sabetan & Gerak penghubung \\
\hline & & $\begin{array}{l}\text { Sekaran kambengan } \\
\text { kanan kiri }\end{array}$ & Gerak sekaran \\
\hline & & Mere & Kesan marah \\
\hline & & Trecetan & Kesan kegirangan \\
\hline & & Kambengan & Gerak sekaran \\
\hline & & Perangan & $\begin{array}{l}\text { Gerak sekaran yang memiliki kesan } \\
\text { bertarung }\end{array}$ \\
\hline & & Roll depan & kesan dijatuhkan lawan \\
\hline & & Kambengan & Gerak sekaran \\
\hline & & $\begin{array}{l}\text { Sekaran ogek } \\
\text { lambung }\end{array}$ & Gerak sekaran \\
\hline & & Besut mbandul & Gerak penghubung \\
\hline & & Mere & Kesan marah \\
\hline & & Tanjak kambeng & Kesan gagah \\
\hline & & Endhan & Kesan menghindar menghindar \\
\hline & & Sabetan & Gerak penghubung \\
\hline & & $\begin{array}{l}\text { Sekaran kambengan } \\
\text { kanan kiri }\end{array}$ & Gerak sekaran \\
\hline & & Lompat Katak & Kesan bahagia, kegirangan \\
\hline & & Kambengan & Gerak sekaran \\
\hline & & $\begin{array}{l}\text { Perangan (perang } \\
\text { tangkepan) }\end{array}$ & $\begin{array}{l}\text { Gerak sekaran yang memiliki kesan } \\
\text { bertarung }\end{array}$ \\
\hline
\end{tabular}




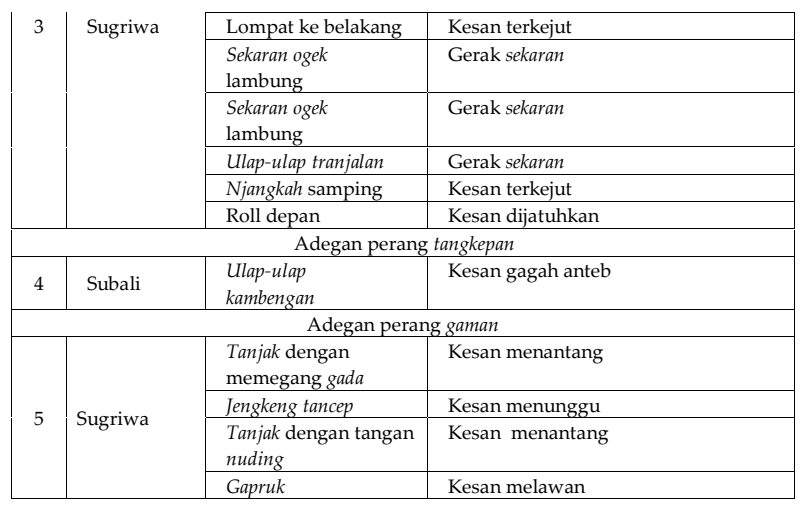

Tabel 7. Rekapitulasi Gerak Representatif dan Presentatif Fragmen Tari Sugriwa Subali.

\begin{tabular}{|c|c|c|c|c|}
\hline \multirow{2}{*}{ No } & \multirow{2}{*}{ Babak } & \multirow{2}{*}{ Nama Tokoh } & \multicolumn{2}{|c|}{ Jumlah Vokabuler } \\
\hline & & & Representatif & Presentatif \\
\hline \multirow{2}{*}{1} & \multirow{2}{*}{ Babak 1} & Dewi Tara & 15 & 25 \\
\hline & & Sugriwa & 18 & 9 \\
\hline \multirow{3}{*}{2} & \multirow{3}{*}{ Babak 2} & Dewi Tara & 10 & 4 \\
\hline & & Sugriwa & 17 & 18 \\
\hline & & Subali & 22 & 13 \\
\hline \multirow{2}{*}{3} & \multirow{2}{*}{ Babak 3} & Sugriwa & 16 & 16 \\
\hline & & Subali & 24 & 18 \\
\hline \multicolumn{3}{|c|}{ Jumlah Total } & 123 & 103 \\
\hline \multicolumn{3}{|c|}{ Jumlah Presentasi } & $54,42 \%$ & $45,57 \%$ \\
\hline
\end{tabular}

Hasil dari presentase telah menunjukan bahwa gerak representatif dan presentatif dalam Fragmen Tari Sugriwa Subali mempunyai selisih yang cukup signifikan. Tampak bahwa gerak representatif lebih dominan dibanding dengan gerak presentatif. Tarian yang representatif lebih ditunjukan kepada intelektual, pemikiran, serta cenderung realistis dan deskriptif. Tarian yang presentatif lebih pada nilai rasa dan pengembangan imajinasi, serta bukan ditunjukan kepada pengetahuan masalah yang hendak diungkapkan (Jazuli, 2016: 42). Secara garis besar gerak representatif dalam Fragmen Tari Sugriwa Subali menggambarkan suatu peperangan antara dua wanara bersaudara yang terkait dengan masalah percintaan.

\section{Pola Lantai}

Pola lantai merupakan garis yang dibentuk dari gerak tubuh penari yang terlintas pada lantai. Beragam jenis garis yang dibentuk penari pada lantai atau panggung pertunjukan merupakan garis imajiner yang dapat ditangkap dengan kepekaan rasa (Maryono, 2010: 57). Bentuk pola lantai Fragmen Tari Sugriwa Subali memiliki dua macam bentuk pola lantai diantaranya yaitu garis lengkung dan garis lurus. Garis lurus menggambarkan sifat yang kaku, kesan tegas tetapi sederhana, sedangkan garis lengkung memberikan sifat yang memiliki kesan kelembutan. Contoh pola garis lengkung banyak terdapat pada babak pertama adegan pasihan yang di dalamnya menggambarkan kelembutan dan keluwesan sepasang kekasih yang sedang memadu cinta. Sedangkan contoh pola garis lurus banyak terdapat pada babak kedua dan ketiga dimana dalam babak tersebut berisi adegan- adegan yang mengungkapkan ketegangan, seperti halnya perang tangkepab dan perang gaman.

\section{Tata rias}

Rias adalah strategi untuk mengubah wajah pribadi dengan alat- alat kosmetik yang disesuaikan dengan karakter figur supaya tampil lebih percaya diri (Maryono, 2010:58). Rias yang digunakan pada karya ini menggunakan teknik tata rias wayang orang gaya Surakarta. Tata rias wayang orang gaya Surakarta dapat dikategorikan menjadi dua yaitu tata rias realistis dipakai oleh karakter tokoh wayang yang berwujud manusia dan tata rias non realistis hanya berlaku untuk karakter tokoh tertentu diluar karakter yang berwujud manusia (Nuraini, 2011:29). 
Menurut koreografer rias yang digunakan oleh Dewi Tara adalah rias putri lanyap atau endhel, akan tetapi tetap menggunakan alis cantik. Karakter Dewi dalam pewayangan adalah luruh, namun dalam karya ini Dewi Tara dihadirkan dengan tokoh putri lanyap karena untuk kebutuhan ungkapan suasana yang ingin disampaikan (Didik Bambang Wahyudi, wawancara 20 November 2019). Sedangkan tata rias yang digunakan oleh tokoh Sugriwa dan Subali adalah tata rias gagah karakter khusus wanara. Bahan rias yang digunakan dalam tokoh wanara yaitu sinwit warna merah, putih, dan hitam. Pada rias karakter tokoh Sugriwa dan Subali menggunakan warna dasar sinwit merah dan garis-garis pada wajah menggunakan sinwit hitam.

\section{Tata Busana}

Bentuk atau mode busana dalam pertunjukan tari dapat mengarahkan penonton pada pemahaman beragam jenis peran atau figur tokoh. Selain bentuk atau mode, busana juga memiliki warna yang sangat bermakna sebagai simbol-simbol alam pertunjukan. Jenis-jenis simbolis bentuk dan warna busana penari dimaksudkan mempunyai peranan sebagai:

a) Identitas peran, b) karakteristik peran, dan c) ekspresi estetis (Maryono, 2015: 61-62). Berdasarkan uraian tersebut busana merupakan segala perlengkapan yang digunakan pada tubuh, untuk mendukung penggambaran tokoh yang diperankan.

Busana yang dikenakan oleh tokoh Sugriwa dan Subali diantaranya yaitu pada bagian kepala terdapat: irah-irahan gelung kera merah, sumping naga karangrang, dan cangkeman kera merah. Pada bagian badan dan tangan terdapat simbar dada bulu merah, klat bahu naga karangrang, gelang poles, gelang poles bulu merah dan sabuk cindai. Pada bagian pinggang dan kaki terdapat epek timang, sampur gendhalagiri merah, sampur gendhalagiri biru untuk tokoh Subali dan kuning untuk tokoh Sugriwa, uncal, bara samir, jarik poleng bentuk supit urang, celana cindai, binggel serta tubuh dilabur dengan sinwit berwarna merah. Busana yang digunakan oleh Dewi Tara pada bagian kepala di antaranya yaitu: irah-irahan gelung gondhel, plim rambut, kantong gelung, giwang/ceplik dan sumping kudup naga karangrang. Pada bagian badan dan tangan terdapat kalung, klat bahu, gelang, mekak payet warna hitam, slepe dan sampur krepyak warna merah muda. Pada bagian pinggang dan kaki terdapat jarik samparan. motif parang. Berikut ini adalah ricikan kostum Dewi Tara beserta pengertianya.

\section{Properti}

Keberadaan properti atau alat-alat bantu yang digunakan sebagai peraga penari sifatnya tentatif. Masing-masing karya tari memiliki cara, gaya, dan model berekspresi yang berbeda-beda. Kehadiran properti tari memiliki peranan sebagai: a) senjata, b) sarana ekspresi, dan c) sarana simbolik (Maryono, 2015: 67-68). Pada karya Fragmen Tari Sugriwa Subali ini properti berperan sebagai senjata dan sarana ekspresi pada bagian perang. Properti yang digunakan dalam karya ini yaitu gada. Gada adalah senjata yang terbuat dari kayu dan ada pula yang terbuat dari kuningan. Gada digunakan sebagai alat pemukul ataupun penangkis. Properti ini hanya digunakan pada babak ketiga adegan perang gaman, yang digunakan 
oleh tokoh Sugriwa saat sedang melawan Subali. Kehadiran properti ini dimaksudkan agar bisa menyetarakan kesaktian diantara Sugriwa dan Subali (Didik Bambang Wahyudi, wawancara 26 November 2019).

\section{Musik atau Karawitan Tari}

Musik atau karawitan tari dalam seni pertunjukan memegang peranan sangat penting yaitu sebagai: (a) petunjuk isi, (b) ilustrasi / nglambari, (c) membungkus / mungkus, (d) menyatu / nyawiji (Maryono, 2010: 59). Karawitan tari dalam karya ini digarap oleh Wahyu Santoso Prabowo. Berikut analisis musik dalam karya Fragmen Tari Sugriwa Subali.

Babak pertama diawali dengan kemunculan Dewi Tara yang diiringi dengan buka rebab ladrang peksi kuwung dengan suasana gendhing mengungkapkan kenyamanan, kebahagiaan, dan keceriaan. Ketika masuk vokal gerongan ladrang peksi kuwung laras slendro nem suasana berubah menjadi agung dan tenang. Babak kedua diawali dengan peralihan gendhing yang memunculkan suasana tegang. Bersamaan dengan kemunculan Subali dengan garap gedhing srepeg lasem. Dalam adegan ini mengungkapkan kemarahan Subali yang didukung dengan adanya syair tembang palaran sinom manyura pathet nem. Palaran dilagukan oleh ketiga tokoh secara bergantian. Dalam adegan ini musik berperan nyawiji, karena membangun suasana konflik, greget, serta ungkapan kemarahan Subali terhadap Dewi Tara dan Sugriwa. Dilanjut pada adegan berikutnya dimana Sugriwa dan Subali saling menunjukan kecongkakannya. Didukung dengan garap gendhing srepeg lasem (Wahyu
Santoso Prabowo, wawancara 25 November 2019).

Babak ketiga adegan beksan dengan garap gendhing ladrang jungkung laras slendro nem dengan peran gendhing nyawiji. Pada perang tangkepan diawali dengan srepegan sebagai awalan saat perang atau dapat disebut pula peralihan. Perang tangkepan diawali dengan gerak capengan, dengan peran musik mungkus dengan menghadirkan suasana ketegangan. Mungkus merupakan konsep karawitan tari yang dimaksudkan dapat membingkai terhadap gerak-gerak penari (Maryono, 2015:66). Selanjutnya pada perang gaman yang berisi ungkapan rasa Subali terhadap Sugriwa dilihat dari syair tembang palaran durma. Palaran durma mengandung ungkapan saling menantang sebagai awalan perang gaman. Pada bagian perang gaman menggunakan garap gendhing srepeg slendro manyura, lalu berubah dengan suasana yang memuncak, dengan didukung gendhing sampak slendro manyura. (Wahyu Santoso Prabowo, wawancara 25 November 2019).

Secara garis besar pada pembahasan sensasi yang diungkapkan dengan komponen nonverbal dalam pertunjukan Fragmen Tari Sugriwa Subali dapat menggambarkan peperangan antara Sugriwa dan Subali dalam memperebutkan Dewi Tara.

\section{KONSEP ATAU GAGASAN ESTETIK}

Konsep atau gagasan suatu arti dapat menimbulkan emosi yang tidak samarsamar, tetapi memiliki arti yang pasti yang berhubungan dengan gagasan yang merupakan isi dan arti pada medium. Pada dasarnya karya seni bukan ungkapan pribadi tetapi merupakan ungkapan yang 
dapat dikomunikasikan sehingga sifatnya universal (Maryono, 2015:142). Karya ini menghadirkan konsep atau gagasan mengenai hak dan kebenaran. Konsep atau gagasan mengenai hak yang dimaksudkan dalam karya ini adalah hak menerima Dewi Tara yang diberikan oleh para Dewa kepada Sugriwa atau Subali yang berhasil melaksanakan kewajiban untuk memusnahkan Mahesasura dan kedua patihnya yang bermaksud ingin menghancurkan khayangan. Serta kebenaran yang dimaksud dalam karya ini terletak pada diri Sugriwa dan Subali. Kebenaran Sugriwa adalah ketika Sugriwa melaksanakan perintah dari kakaknya Subali untuk segera menutup pintu goa apabila mengalir darah putih, yang menandakan bahwa Subali berhasil dikalahkan musuh. Namun pada realitanya darah merah mengalir bercampur dengan darah putih. Tanpa pikir panjang Sugriwa langsung menutup goa, dan menganggap Subali telah mati sampyuh. Kebenaran Subali adalah keberhasilan dalam melaksanakan kewajiban yang diberikan para Dewa untuk mengalahkan musuh para dewa (Didik Bambang Wahyudi, wawancara 30 Desember 2019).

Mencermati konsep atau gagasan dalam ini selain melakukan wawancara dengan narasumber utama, peneliti juga harus mencermati konsep atau gagasan yang terdapat pada komponen yang bersifat verbal. Hal ini sejalan dengan pernyataan Maryono, yang mengungkapkan bahwa:

Komponen verbal adalah jenis- jenis unsur atau elemen yang berbentuk kebahasaan. Dalam seni pertunjukan komponen verbal adalah komponen yang berfungsi untuk petunjuk isi atau pesan makna dan penyampai isi atau pesan makna (2015:25).

Untuk mengupas komponen verbal dalam karya ini menggunakan teori tindak tutur menurut Kreidler (1998) yang membagi tuturan menjadi tujuh jenis tindak tutur, diantaranya yaitu asertif, performatif, verdiktif, ekspresif, direktif, komisif, dan patik (dalam Maryono, 2010:36-38). Jenisjenis teks verbal yang ada dalam karya ini terurai pada adegan disetiap babak. Gerongan ladrang peksi kuwung slendro nem terdapat pada babak pertama adegan pasihan antara Dewi Tara dan Sugriwa. Palaran sinom manyura pathet nem terdapat pada babak kedua dalam adegan perebutan Dewi Tara oleh Sugriwa dan Subali. Palaran durma terdapat pada babak ke tiga dalam adegan perang gaman.

Tabel 11. Jenis-jenis Tindak Tutur (TT) yang melekat pada teks Gerongan Ladrang Peksi Kuwung.

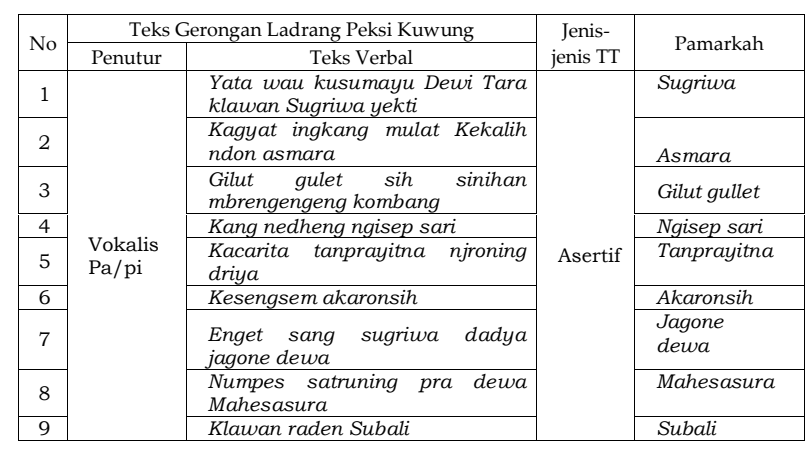

Tabel 12. Jenis-jenis Tindak Tutur (TT) yang melekat pada teks Palaran Sinom Manyura.

\begin{tabular}{|c|c|c|c|c|}
\hline \multirow{2}{*}{ No } & \multicolumn{2}{|c|}{ Teks Palaran Sinom Manyura } & \multirow{2}{*}{$\begin{array}{l}\text { Jenis-jenis } \\
\text { TT }\end{array}$} & \multirow{2}{*}{ Pamarkah } \\
\hline & Penutur & Teks Verbal & & \\
\hline \multirow{3}{*}{1} & & Dewi Tara tan kanyana & Verdiktif & Tan kanyana \\
\hline & & Tan setya marang wak mami & Ekspresif & Tan setya \\
\hline & Subali & $\begin{array}{l}\text { Kasluru andon asmara } \\
\text { Murang tata patrap julig }\end{array}$ & Verdiktif & patrap julig \\
\hline 2 & $\begin{array}{l}\text { Dewi } \\
\text { Tara }\end{array}$ & $\begin{array}{l}\text { Pawarta duk ing nguni } \\
\text { Kakang Subali } \\
\text { wus lampus }\end{array}$ & \multirow{3}{*}{ Asertif } & $\begin{array}{l}\text { Pawatrta dak } \\
\text { king nguni }\end{array}$ \\
\hline 3 & Sugriwa & $\begin{array}{l}\text { Mijil ludira seta dadya } \\
\text { tandha rah nyawiji }\end{array}$ & & $\begin{array}{l}\text { Mijil Ludhira } \\
\text { seta }\end{array}$ \\
\hline 4. & Subali & $\begin{array}{l}\text { Heh Sugriwa, candhala } \\
\text { bebudenira }\end{array}$ & & $\begin{array}{l}\text { candhara } \\
\text { bebudenira }\end{array}$ \\
\hline
\end{tabular}


Table 13. Jenis-jenis Tindak Tutur (TT) yang melekat pada Palaran durma.

\begin{tabular}{|c|c|c|c|c|}
\hline \multirow[b]{2}{*}{ No } & \multicolumn{2}{|r|}{ Teks Palaran Durma } & \multirow{2}{*}{$\begin{array}{c}\text { Jenis-jenis } \\
\text { TT }\end{array}$} & \multirow{2}{*}{ Pamarkah } \\
\hline & Penutur & Teks Verbal & & \\
\hline \multirow[t]{2}{*}{1.} & \multirow[t]{2}{*}{ Sugriwa } & Heh Subali aja sira sesongaran & Direktif & $\begin{array}{l}\text { aja sira } \\
\text { sesongaran }\end{array}$ \\
\hline & & $\begin{array}{l}\text { Tandhing yudha mring wak } \\
\text { mami }\end{array}$ & & $\begin{array}{l}\text { Tandhing } \\
\text { yudha }\end{array}$ \\
\hline \multirow[t]{2}{*}{2} & \multirow[t]{2}{*}{ Subali } & Sira murang tata & Verdiktif & murang tata \\
\hline & & $\begin{array}{l}\text { Datan kulak pawarta } \\
\text { Ingsun durung tekeng lalis } \\
\text { coba rasakno }\end{array}$ & Asertif & $\begin{array}{l}\text { kalak } \\
\text { pawarta }\end{array}$ \\
\hline 3 & Sugriwa & Sapa lena ngemasi & Ekspresif & Angemasi \\
\hline
\end{tabular}

Merujuk pada analisis komponen verbal dalam Fargmen Tari Sugriwa Subali dapat diungkap sebagai berikut. Teks gerongan pada ladrang peksikuwugslendro nem mengungkapkan sebuah kisah percintaan yang penuh dengan kasih sayang dan bahagia antara seorang bidadari bernama Dewi Tara dengan seorang raja wanara bernama Sugriwa. Teks palaran sinom manyura pathet nem mengungkapkan kemarahan subali terhadap Dewi Tara dan raja wanara Sugriwa karena Subali merasa telah dikhianati. Teks palaran durma mengungkapkan peperangan hebat antara tokoh Sugriwa dan Subali dalam memperebutkan Dewi Tara. Secara garis besar konsep atau gagasan dalam Fragmen Tari Sugriwa Subali mengungkapkan hak dan kebenaran menurut Sugriwa dan Subali dalam memperebutkan Dewi Tara.

\section{LAMBANG ESTETIK}

Lambang atau simbol dalam Kamus Besar Bahasa Indonesia memiliki arti sesuatu seperti tanda (lukisan, lencana dan lain-lain) yang menyatakan suatu hal yang mengandung maksud tertentu (2005:630). Suatu lambang dapat digunakan sebagai tanda untuk memaknai suatu bentuk. Menurut De Witt H Parker yaitu:

Simbolisasi adalah fungsi untuk melambangi benda, peristiwa atau universal. Warna, garis, dan bentuk lukisan pemandangan alam dapat menarik dan memikat manusia bukan hanya karena sebagai warna, garis dan bentuk saja, melainkan juga merupakan lambang-lambang dari pohon, awan, bukit, rumah, sawah, ladang, air, sungai, matahari dan lainnya (1980:77).

Kehadiran Fragmen Tari Sugriwa Subali dalam kehidupan masyarakat rupanya tidak sekedar sebagai seni pertunjukan saja yang hanya berfungsi sebagai tontonan atau hiburan semata, akan tetapi memiliki simbol atau lambang. Dalam analisis ini akan diawali dengan mencermati karakter masing-masing tokoh yaitu Dewi Tara, Sugriwa dan Subali yang merupakan bagian komponen karya yang berkaitan langsung dengan komponen baik yang bersifat verbal maupun nonverbal. Dewi Tara dalam karya Fragmen Tari Sugriwa Subali Dewi Tara divisualisasikan sebagai seorang wanita yang berparas cantik, bersifat anggun, dengan karakter luruh yang bernuansa lanyap (Didik Bambang Wahyudi, wawancara 30 Desember 2019). Hal tersebut dapat dilihat melalui elemen-elemen pendukungnya, seperti keanggunan Dewi Tara dapat dilihat pada garis-garis rias karakter yang meliputi alis, celak, sipatan, laler menclok dan garis pada bibir. Kecantikan Dewi Tara terlihat pada pemilihan warna-warna rias wajahnya. Warna tersebut meliputi warna pada eyeshadow, lipstik, dan blush on. Pemilihan warna pada rias dengan pengaplikasian yang tepat pada tokoh Dewi Tara dapat memberikan kesan wajah wanita yang cantik.

Dewi Tara memiliki karakter luruh yang bernuansa lanyap. Pada dasarnya Dewi 
Tara itu memiliki karakter yang luruh. Adapun nuansa lanyap yang dimunculkan merujuk pada kebutuhan suasana kemarahan dan kebimbangan Dewi Tara. Kecantikan busana yang digunakan tokoh Dewi Tara terdapat pada jarik samparan, mekak, ilat-ilatan, slepe, muk, klat bahu grudo, dan sampur. Selain itu juga dimunculkan dengan dukungan perhiasan yang berwarna kuning keemasan. Keanggunan pada busana tokoh Dewi Tara dapat dilihat dari pemilihan warna-warna yang sesuai. Warna busana pada tokoh Dewi Tara banyak didominasi dengan warnawarna hitam dan kuning keemasan. Menurut Maryono warna hitam pada pertunjukan tari memiliki kesan bijaksana, berwibawa, dan anggun (2015:62). Sedangkan warna kuning keemasan memiliki kesan glamor atau mempesona, mewah, keagungan, kejayaan, dan bijaksana (Maryono, 2015:63). Karakter lanyap pada Dewi Tara dapat dicermati dari irah-irahan gelung gondhel. Irah-irahan gelung gondhel memiliki bentuk jamang yang lanyap (runcing) dengan disertai garuda mungkur.

Elemen pendukung karakter Dewi Tara yang berparas cantik, anggun, dan berkarakter luruh yang bernuansa lanyap terdapat pada garis, warna dan bentuk pada pola geraknya. Karakter luruh merupakan karakter dasar dari tokoh Dewi Tara yang dapat dicermati dari bentuk pola motif-motif gerak seperti srisig miwir sampur, sekaran lembehan separo, srisig menthang kiri, srisig mundur ngolong sampur, dan sekaran timbotimbo. Karakter Dewi Tara yang bernuansa lanyap dapat dicermati dari bentuk pola motif-motif gerak seperti sekaran sukarsih, sekaran golek iwak, enjer kanan, hoyogan ulapulap, lumaksono ridong sampur, kapang- kapang dan gerak srisigan yang didukung dengan irama musik dengan tempo yang dinamis.

Karakter Sugriwa yang lincah, trengginas, dan pantang menyerah tergambar pada garis-garis yang terbentuk dari rias karakter wanara yang banyak dimunculkan dengan garis lengkung yang meruncing pada bagian ujungnya seperti garis pada pada alis, kelohan, sipatan, dan garis kerutan. Karakter tersebut juga dapat dilihat dari busana yang digunakan. Sugriwa menggunakan busana kera wanara dengan nuansa warna merah dimana warna merah melambangkan keberanian, agresif, dan dinamis (Maryono, 2015: 62). Pada busana, terletak perbedaan pada warna sampur yang digunakan oleh tokoh Sugriwa dan Subali. Sugriwa menggunakan warna kuning yang melambangkan sifat yang cakrak atau gesit (berjiwa muda) (Didik Bambang Wahyudi, 16 Desember 2019). Elemen pendukung karakter Sugriwa yang lincah trengginas dan pantang menyerah terdapat pada warna geraknya yang termasuk pada gerak karakter khusus wanara. Dapat dilihat dari gerak-gerak melompat, meloncat, capengan, sekaran laku telu, onclangan yogjan, dan sekaran ogek lambung. Adapun sifat Sugriwa yang pantang menyerah terdapat pada babak ketiga yang berisi perangan.

Karakter Subali dalam karya ini yaitu karakter gagah anteb atau tenang, berwibawa dan trengginas dapat dilihat dari pola garis pada wajah dengan garis lengkung dan meruncing. Rias pada Subali terlihat lebih sederhana daripada rias pada Sugriwa. Hal tersebut dapat memberi kesan yang tegas, tenang, dan mantap. Dilihat dari busana Subali secara garis besar sama, 
namun sedikit ada perbedaan pada pemilihan warna sampur. Subali menggunakan sampur berwarna biru yang melambangkan sifat tenang (Didik Bambang Wahyudi, 16 Desember 2019).

Karakter antep atau tenang dan berwibawa ketika dilihat dari pola geraknya. Secara umum antara kedua tokoh wanara pola geraknya hampir sama, namun pembawaan tokoh Subali lebih tenang untuk memunculkan kesan antep dan berwibawa yang dapat dilihat dari pola gerak kambengan dengan musik yang dinamis dengan gerak-gerak yang tenang. Selain Sugriwa, Subali juga memiliki karakter yang trengginas, hal ini dapat dicermati pada pola-pola gerak dalam adegan perangan.

Berdasarkan simbol yang diungkap melalui struktur sajian secara keseluruhan baik bersifat verbal maupun non verbal karya Fragmen Tari Sugriwa Subali melambangkan suatu kebahagiaan yang dapat diperoleh dengan cara berjuang mempertahankan hak dan kebenaran tanpa ada rasa putus asa dan pantang menyerah.

\section{TANGGAPAN PENONTON}

Tanggapan adalah pendapat atau reaksi yang ditunjukan seseorang setelah melihat, mendengar, ataupun merasakan sesuatu (2005:526). Hal tersebut erat kaitannya dengan perasaan seseorang yang tidak lepas dari kekuatan pacu yang muncul dari suatu karya, seperti halnya dalam karya Fragmen Tari Sugriwa Subali yang dalam pertunjukannya mampu memikat, menarik, dan mengundang penonton untuk menghayatinya. Secara mendasar berkaitan dengan masalah penghayatan, Parker menyatakan bahwa:
Lukisan seni adalah bukan lukisan benda semata, melainkan lukisan tentang tangkapan seniman tentang benda itu, perasaan atau emosi yang disebabkan oleh benda itu (1980:27).

Berdasarkan pernyataan tersebut, pada dasarnya keindahan itu terletak pada jiwa manusia yang setiap saat dapat tersentuh dan tergugah oleh benda-benda yang memiliki nilai pacu setelah mengamati karya seni (Maryono, wawancara 24 Oktober 2019). Berdasarkan emosional atau tanggapan para pakar, penari dan penonton dapat ditarik intinya bahwa Karya Fragmen Tari Sugriwa Subali menggambarkan peperangan Sugriwa dan Subali yang memperebutkan Dewi Tara. Dewi Tara dimanifestasikan sebagai sumber kekuatan alam seperti halnya Dewi Shinta dalam epos Ramayana dan Dewi Sekartaji dalam babat Panji. Kesepadanan Dewi Tara sebagai lambang kebahagiaan dengan Dewi Shinta dalam epos Ramayana, yang dilambangkan sebagai Dewi kemakmuran dan kebahagiaan. Dalam cerita pewayangan Dewi Shinta sebagai lambang kemakmuran dan kebahagiaan direbut oleh Rahwana dari tangan Ramawijaya dengan pengorbanan kehancuran Negara Alengka dan raja beserta senopatinya yang gugur di medan perang. Dalam hal ini rupanya Dewi Tara merupakan kekuatan alam sebagai lambang kemakmuran dan kebahagiaan yang layak untuk diperjuangkan sebagai miliknya.

\section{PENUTUP}

Berdasarkan bentuk sensasi, konsep atau gagasan, lambang atau simbolisasi, dan tanggapan para pakar, penari dan penonton secara estetis Fragmen Tari Sugriwa Subali 
merupakan sebuah karya yang menggambarkan suatu peperangan antara Sugriwa dan Subali dalam memperebutkan Dewi Tara yang berfungsi sebagai hiburan estetis bagi para penonton dan juga sebagai lambang perjuangan dalam memperoleh suatu kebahagiaan. Pada dasarnya dalam kehidupannya, manusia tidak lepas dari kebutuhan yang bersifat material dan imaterial. Kebutuhan yang bersifat material adalah kebutuhan yang berbentuk benda sedangkan kebutuhan imaterial adalah kebutuhan benda yang tidak berwujud seperti kebutuhan jiwa. Karya ini dapat memberi sumbangan pada kebutuhan manusia yang bersifat imaterial yang mampu membuat penonton menjadi senang, gembira, dan dapat menambah pengalaman secara estetis. Karya Fragmen Tari Sugriwa Subali selain sebagai hiburan juga sebagai lambang perjuangan dalam memperoleh suatu kebahagiaan. Lambang atau simbolisasi perjuangan karya Fragmen Tari Sugriwa Subali dimanifestasikan dalam wujud tokoh Sugriwa dan Subali dalam mempertahankan hak dan kebenarannya masing-masing untuk mendapatkan Dewi Tara sebagai lambang kebahagiaan.

\section{DAFTAR PUSTAKA}

Haryono, Sutarno. 2010. Kajian Pragmatik Seni Pertunjukan Opera Jawa. Surakarta: ISI Press Solo.

Jazuli, M. 2016. Peta Dunia Seni Tari. Sukoharjo: CV. Farishma Indonesia.

Kartika, Dharsono Sony. 2004. Pengantar Estetika. Bandung: Rekayasa Sains.
Maryono, 2010. Pragmatik Genre Tari Pasihan Gaya Surakarta. Surakarta: ISI Press Solo ,2010. “Estetika Seni Pertunjukan Tari" Greget, Jurnal Pengkajian dan Penciptaan Seni Vol. 9 No. 2 (Desember 2010): 135-145.

, 2011. Penelitian Kualitatif Seni

Pertunjukan. Surakarta: ISI Press Solo 2015. Analisa Tari. Surakarta: ISI Press Solo.

Moehkardi. 2011. Sendratari Ramayana Prambanan Seni dan Sejarahnya. Bogor: Grafika Mardi Yuana.

Moleong, Lexy J. 1995. Metodologi Penelitian Kualitatif. Bandung: PT. Remaja Rosdakarya.

Nuraini, Indah. 2011. Tata Rias dan Busana Wayang Orang Gaya Surakarta. Yogyakarta: Badan Penerbit ISI Yogyakarta.

Parker, De Witt H. Parker. 1970. Dasar-dasar Estetik, diindonesiakan oleh SD Humardani. Surakarta: Sub Proyek Pengembangan IKI.

Sunardi. 2002. Ramayana. Jakarta: Balai Pustaka.

Sutopo. 2006. Metodologi Penelitian Kualitatif. Surakarta: UNS. 